\title{
Produção de Micélio de Crinipellis perniciosa em Quatro Meios de Cultura, Visando Extração de DNA*
}

\author{
Fábio G. Faleiro**1,3, Givaldo R. Niella², Ana Rosa R.N. Cerqueira², Virgínia O. Damaceno², Luana M.C. \\ Gomes $^{1}$ \& Alessandra S.G. Faleiro ${ }^{1}$
}

${ }^{1}$ Laboratório de Biotecnologia, Seção de Genética, ${ }^{2}$ Seção de Fitopatologia, CEPEC/CEPLAC, Cx. Postal 07, CEP 45600-000, Itabuna, BA; ${ }^{3}$ Embrapa Cerrados, Cx. Postal 08223, CEP 73301-970, Planaltina, DF, e-mail: ffaleiro@ @ cpac.embrapa.br

(Aceito para publicação em 27/01/2003)

Autor para correspondência: Fábio Gelape Faleiro

FALEIRO, F.G., NIELLA, G.R., CERQUEIRA, A.R.R.N., DAMACENO, V.O., GOMES, L.M.C. \& FALEIRO, A.S.G. Produção de micélio de Crinipellis perniciosa em quatro diferentes meios de cultura, visando extração de DNA. Fitopatologia Brasileira 29:312-315. 2004.

\section{RESUMO}

A produção de massa micelial é o primeiro passo para obter amostras de DNA de qualidade e quantidade suficiente para análises moleculares. Neste trabalho, objetivou-se analisar a quantidade e a qualidade do DNA de Crinipellis perniciosa extraído a partir de massa micelial obtida em quatro meios de cultura. Foi avaliado o peso de micélio liofilizado produzido nos seguintes meios de cultura: 1 . extrato de levedura $(2,5 \%) ; 2$. extrato de malte $(2,5 \%) ; 3$. BD (batata $20 \%$ e dextrose $2 \%$ ) e 4 . extrato de malte $+\mathrm{BD}(50 \%$ de cada meio). $\mathrm{O}$ crescimento micelial foi iniciado a partir de um disco de micélio colocado no centro de placas de Petri de $90 \mathrm{~mm}$ contendo o meio testado e mantidas a $25^{\circ} \mathrm{C}$ e fotoperíodo de $12 \mathrm{~h}$, por dez dias. Foi utilizado o DIC com dez repetições. O micélio produzido foi liofilizado e o DNA extraído utilizando-se o método do SDS com a desproteinização feita com ou sem fenol. A pureza do DNA baseada na relação $\mathrm{A}_{260} / \mathrm{A}_{280}$ e a integridade em gel de agarose $0,8 \%$ foram analisadas. A quantidade de micélio produzida nos meios de cultura 1 e 4 foi maior do que nos meios 2 e 3 . O DNA extraído a partir de micélio produzido nos meios 2 e 3 apresentou maior integridade, obtendo-se produtos de amplificação mais nítidos. A desproteinização com fenol possibilitou a extração de DNA mais puro. Porém, DNA de ótima qualidade e em quantidade suficiente pode ser extraído a partir de micélio produzido em meios baratos como o BD, sem a necessidade da desproteinização com fenol. Palavras-chave adicionais: vassoura-de-bruxa, cacau, metodologia.

\section{ABSTRACT}

\section{Mycelial production of Crinipellis perniciosa on four culture media for DNA extraction}

Mycelial production is the first step in getting good quality and quantity of DNA samples for molecular analysis. The objective of this work was to analyse the quantity and quality of DNA extracted from Crinipellis perniciosa mycelial mass obtained on four culture media. The lyophilized mycelial mass weight was evaluated in the following culture media: 1 . yeast extract $(2.5 \%) ; 2$. Malt extract $(2.5 \%) ; 3$. PD (potato $20 \%$ and dextrose $2 \%$ ) and 4 . malt extract + PD (50\% of each culture media 2 and 3). Mycelial growth was produced by depositing of a mycelial disk in the center of $90 \mathrm{~mm}$ Petri dishes containing each culture medium. The dishes were kept in a BOD incubator at $25^{\circ} \mathrm{C}$ under a photoperiod of $12 \mathrm{~h}$, for ten days. The experiment was organized in complete random design with ten repetitions. The DNA was extracted from $250 \mathrm{mg}$ of lyophilizated mycelial mass using the SDS method with desproteinization carried out either with or without phenol. The DNA purity based on the absorbance $\mathrm{A}_{260} / \mathrm{A}_{280}$ and the DNA integrity in agarose gel $0,8 \%$ were analyzed. The quantity of mycelial massproduced on culture media 1 and 4 was larger than on culture media 2 and 3. The DNA extracted from the mycelial mass produced in culture media 2 and 3 demonstrated greater integrity, yielding good amplification products. The DNA purity was higher after desproteinization with phenol. However, good quality and abundant DNA could be extracted from the mycelial mass produced in PD, even without desproteinization with phenol.
Crinipellis perniciosa (Stahel) Singer é o agente etiológico da vassoura-de-bruxa do cacaueiro (Theobroma cacao L.), a qual se constitui na principal limitação para a produção de cacau na América do Sul, Panamá e nas ilhas do Caribe (Thorold, 1975). No Brasil, esta doença tem causado sérios problemas econômicos, sociais e ecológicos, principalmente na região sul da Bahia, onde perdas ocasionadas pelo fungo chegam a atingir $100 \%$ em algumas fazendas.

O conhecimento da variabilidade genética do patógeno

\footnotetext{
* Auxílio financeiro: CFC/ICCO/CEPLAC-BIOMOL e FUNDECAU

** Bolsista do IBECAU
}

tem grande importância em estudos de patogenicidade e relacionados ao melhoramento genético do cacaueiro visando a sua resistência à doença. Diferentes tipos de marcadores moleculares e análises de seqüências do DNA vêm sendo utilizados com sucesso na caracterização da variabilidade genética de diferentes fitopatógenos, incluindo-se C. perniciosa (Anderbrhan et al., 1994, 1999; Gomes et al.; 2000a, b). A obtenção de massa micelial para extração de DNA de qualidade e em quantidade suficiente para as análises moleculares é fundamental para a realização de tais estudos.

A quantidade e a qualidade do DNA depende da 
Produção de micélio de Crinipellis perniciosa em quatro meios de...

quantidade e qualidade da massa micelial produzida. Diferentes meios de cultura (Dhingra \& Sinclair, 1995) podem ser utilizados para a produção de massa micelial de $C$. perniciosa. No entanto, vários critérios devem ser considerados na escolha do meio de cultura para produção de massa micelial para extração de DNA, tais como o grau de pureza da massa micelial produzida, a facilidade de separação da massa micelial do meio de cultura, a velocidade do crescimento micelial, o custo do meio de cultura e a qualidade e quantidade do DNA extraído a partir da massa micelial obtida.

Os protocolos de extração e purificação do DNA também influenciam a qualidade e quantidade do DNA isolado. Diferentes métodos têm sido utilizados para a extração de DNA de $C$. perniciosa, a partir de massa micelial, incluindo-se aqueles que utilizam o detergente catiônico CTAB (cetyltrimethylammonium bromide) (Anderbrham et al., 1999) ou o detergente aniônico SDS (sodium dodecyl sulfate) (Gomes et al., 2000a) no tampão de extração. Pequenas variações nos métodos de extração de DNA são relatadas na literatura tais como a mudança de concentração de um ou outro componente do tampão de extração, tempos e força gravitacional das centrifugações e a utilização ou não de fenol no processo de desproteinização.

Neste trabalho, objetivou-se analisar a produção de massa micelial de $C$. perniciosa em quatro diferentes meios de cultura, analisar a quantidade e a qualidade do DNA extraído a partir de massa micelial obtida em cada meio e analisar a pureza do DNA extraído, utilizando-se o processo de desproteinização com e sem o uso de fenol.

Foram utilizados quatro meios de cultura líquidos: 1. extrato de levedura $(2,5 \%) ; 2$. extrato de malte $(2,5 \%) ; 3$. BD ( $20 \%$ de batata e $2 \%$ de dextrose) e 4 . extrato de malte + BD ( $50 \%$ do meio 1 e $50 \%$ do meio 3). Não foi feito ajuste de $\mathrm{pH}$ nos respectivos meios. O crescimento do micélio em cada meio de cultura foi iniciado a partir de um único disco de cultura monospórica, cultivada em BDA (20\% de batata, $2 \%$ de dextrose e $2 \%$ de ágar em água), o qual foi colocado no centro de cada placa de Petri de $90 \mathrm{~mm}$, contendo $10 \mathrm{ml}$ do meio de cultura avaliado. Para cada meio de cultura, foram utilizadas dez placas de Petri, as quais, após o semeio, foram mantidas em incubadora BOD com temperatura ajustada para $25^{\circ} \mathrm{C}$ e fotoperíodo de 12 $\mathrm{h}$, durante dez dias. Após esse período, o micélio produzido em cada placa de Petri foi separado do meio de cultura e, em seguida, liofilizado. Foi avaliado o peso do micélio liofilizado. Análises de variância foram feitas segundo um delineamento inteiramente casualizado com dez repetições. Para a comparação das médias, foi utilizado o teste de Tukey, a $1 \%$ de probabilidade.

O micélio liofilizado produzido em cada um dos meios de cultura foi utilizado para a extração do DNA. Foram feitas quatro extrações de DNA a partir de massa micelial obtida em cada meio de cultura. O DNA foi isolado utilizando-se o método do SDS utilizado por Gomes et al. (2000a) como segue: 250 mg de micélio liofilizado foi macerado em cadinho de porcelana em contato com $\mathrm{N}_{2}$ líquido. Em seguida, o micélio macerado foi colocado em um tubo plástico de $1,5 \mathrm{ml}$, ao qual foi adicionado $700 \mu \mathrm{l}$ de tampão de extração constituído por Tris-
HCl 200 mM (pH 8,0), EDTA 25 mM, dodecil sulfato de sódio $1 \%, \mathrm{NaCl} 250 \mathrm{mM}$ e 2-mercaptoetanol 1\%. O micélio macerado foi misturado ao tampão de extração e os tubos foram mantidos em banho-maria $\left(70^{\circ} \mathrm{C}\right)$ por $1 \mathrm{~h}$, sendo agitados, a cada $10 \mathrm{~min}$. Após a incubação, foram realizados dois procedimentos para a desproteinização (com e sem fenol), sendo que cada procedimento foi realizado em duas amostras de massa micelial obtida de cada meio de cultura. No procedimento com fenol, foi adicionado em cada amostra $300 \mu \mathrm{l}$ da mistura clorofórmioálcool isoamílico $(24: 1 \mathrm{v} / \mathrm{v})$ e $300 \mu \mathrm{l}$ de fenol e no procedimento sem fenol foi adicionado $600 \mu \mathrm{l}$ de clorofórmio-álcool isoamílico (24:1 v/v). Em seguida, as amostras foram agitadas, por suaves inversões, por 10 min e centrifugadas a $4^{\circ} \mathrm{C}$, a 18.845 $\mathrm{g}$, por $10 \mathrm{~min}$. O sobrenadante de cada amostra foi transferido para tubos de $1,5 \mathrm{ml}$, devidamente limpos, e o processo de desproteinização foi repetido.

Para a precipitação do DNA, foi adicionado ao sobrenadante final $1 / 10$ do seu volume de acetato de sódio $3 \mathrm{M}$, $\mathrm{pH} 5,2$ e $2 / 3$ de isopropanol gelado $\left(4{ }^{\circ} \mathrm{C}\right)$. Os tubos foram mantidos a $-20{ }^{\circ} \mathrm{C}$ por $2 \mathrm{~h}$ e, a seguir, centrifugados como anteriormente. $\mathrm{O}$ sobrenadante foi descartado e o precipitado foi lavado duas vezes com etanol 70\% (v/v) e seco à temperatura ambiente. Posteriomente, os ácidos nucléicos totais foram ressuspendidos em $150 \mu \mathrm{l}$ de água contendo RNAse na concentração de $40 \mu \mathrm{g} / \mathrm{ml}$ e colocados em banho-maria a $37^{\circ} \mathrm{C}$ por $60 \mathrm{~min}$. Após esse período, o DNA foi novamente precipitado, centrifugado e ressuspendido em $100 \mu$ de água, como já descrito.

A quantidade do DNA foi estimada por espectrofotometria a $260 \mathrm{~nm}$ (Sambrook et al., 1989). A relação $\mathrm{A}_{260} / \mathrm{A}_{280}$ foi utilizada para avaliar a pureza do DNA. O perfil eletroforético de $10 \mu \mathrm{l}$ de cada amostra de DNA em gel de agarose $0,8 \%$ corado com brometo de etídio $0,00002 \%$ foi usado como indicador da integridade do DNA. Após esse processo, as amostras de DNA foram diluídas para $10 \mathrm{ng} / \mu \mathrm{l}$ e amplificadas utilizando-se "primers" decâmeros para obtenção de marcadores RAPD ("Random Amplified Polymorphic DNA") (Williams et al., 1990), de acordo com Gomes et al. (2000a).

Foram observadas diferenças significativas entre os meios de cultura quanto à quantidade de micélio produzida, pelo teste Tukey a $1 \%$ de probabilidade. Após dez dias de crescimento, os meios de cultura 4 (Malte + BD) e 1 (Extrato de levedura) produziram maior quantidade de micélio que os meios 2 (Malte) e 3 (BD) (Figura 1). As diferenças na composição química ou no $\mathrm{pH}$ desses meios podem explicar as diferenças observadas.

No processo de extração, verificou-se que a partir das $250 \mathrm{mg}$ de micélio foram obtidos, em média, $25 \mu \mathrm{g}$ de DNA, não havendo diferenças significativas entre a quantidade de DNA obtida a partir das $250 \mathrm{mg}$ de micélio produzidas nos quatro meios de cultura. Observou-se também que a utilização de fenol na etapa de desproteinização possibilitou a obtenção de amostras de DNA mais puro, o que foi observado pela espectrofotometria, com base na relação de absorbância a 260 e $280 \mathrm{~nm}\left(\mathrm{~A}_{260} / \mathrm{A}_{280}\right)$. Tal relação foi mais próxima de 1,8 nas amostras extraídas com a utilização de fenol (dados não apresen 
tados). Faleiro et al. (1996) mostraram que a utilização de fenol no processo de extração foi fundamental para obtenção de DNA de qualidade a partir de uredósporos pré-germinados de Uromyces appendiculatus (Pers.) Unger, agente causador da ferrugem do feijoeiro (Phaseolus vulgaris L.). Contudo, no caso do $C$. perniciosa, observou-se que foi possível a extração de DNA de qualidade e boa pureza (relação $\mathrm{A}_{260} / \mathrm{A}_{280}$ igual a 1,56) a partir de micélio produzido no meio 3 (BD) sem a utilização de fenol, que é um reagente altamente tóxico.

Quanto à integridade do DNA, verifica-se que o DNA extraído a partir de micélio produzido nos meios 2 e 3 apresentaram melhor qualidade (Figura 2). A utilização de fenol (Figura 2A) também contribuiu para o aumento da integridade das amostras de DNA, certamente por melhorar a eficiência do processo de desproteinização. Este aumento da integridade conferida pela utilização de fenol também foi verificado no trabalho de Faleiro et al. (1996).

Pela análise dos resultados (Figura 2), verifica-se que as amostras de DNA extraídas a partir de massa micelial produzida nos meios 1 e 4 apresentaram sérios problemas de integridade, fazendo com que as amostras não fossem visualizadas (Figura 2B). Essa baixa integridade do DNA possivelmente deveu-se a um processo degradativo da massa micelial e, conseqüentemente do próprio DNA, o que pode ter iniciado assim que o crescimento micelial atingiu as bordas da placa de Petri (aproximadamente sete dias após a inoculação). A confirmação dessa hipótese foi feita ao se extrair DNA de boa integridade e qualidade a partir de micélio produzido nos meio ricos (1 e 4) durante cinco dias de crescimento (dados não apresentados). Portanto, a extração de DNA de qualidade a partir de massa micelial de $C$. perniciosa deve ser feita a partir de micélio novo.

Amostras de DNA mais íntegros possibilitaram a

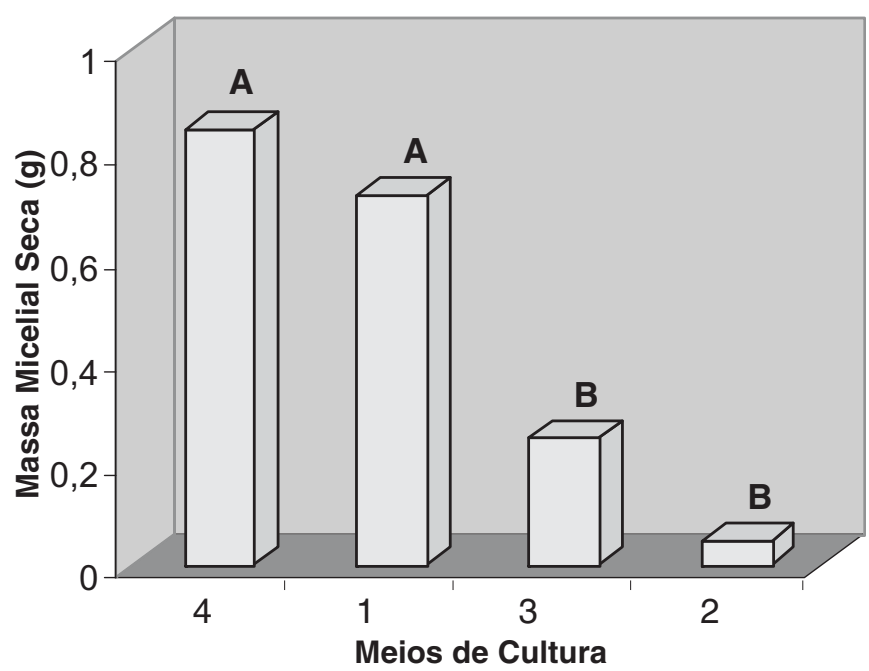

FIG. 1 - Produção de massa micelial seca (g) de Crinipellis perniciosa por placa de Petri após dez dias de crescimento em quatro meios de cultura: 1 . extrato de levedura; 2 . extrato de malte; 3 . BD e 4. extrato de malte $+\mathrm{BD}$. As médias seguidas da mesma letra não diferem entre si a $1 \%$ de probabilidade, pelo teste de Tukey.

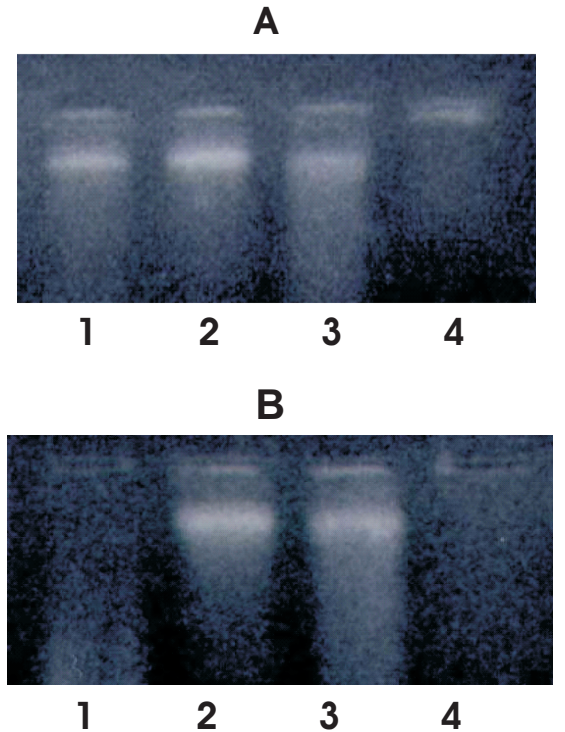

FIG. 2 - Amostras de DNA extraído a partir de micélio de Crinipellis perniciosa produzido nos meios de cultura: 1. extrato de levedura; 2. extrato de malte; 3 . BD e 4. Extrato de malte $+\mathrm{BD}$. As amostras de DNA foram extraídas utilizando-se (A) e não se utilizando fenol (B) durante a desproteinização. Foram aplicados, aproximadamente, 2,5 $\mu \mathrm{g}$ de DNA por amostra.

obtenção de marcadores RAPD mais nítidos e reprodutíveis (dados não apresentados), confirmando a importância da qualidade do DNA extraído para a amplificação via reação em cadeia da polimerase (Williams et al., 1990).

Pode-se concluir que é possível a extração de DNA de C. perniciosa, a partir de massa micelial produzida em meio de cultura barato como o BD, sem a necessidade de desproteinização com fenol (produto altamente tóxico), embora tal reagente melhore a pureza e a integridade do DNA. A utilização de micélio novo de $C$. perniciosa é fundamental para obtenção de amostras de DNA íntegras. O crescimento de massa micelial nos meios 1 e 4 visando extração de DNA deve ser feito por, no máximo, sete dias. Tais procedimentos, provavelmente, podem ser utilizados, com sucesso, na extração de DNA a partir da massa micelial de outros fungos.

\section{REFERÊNCIAS BIBLIOGRÁFICAS}

ANDERBRHAN, T. \& FURTEK, D. Random amplified polymorphic DNA (RAPD) analysis of Crinipellis perniciosa (Stahel) Singer isolates from different hosts. Plant Pathology 43:1020-1027. 1994.

ANDERBRHAN, T., FIGUEIRA, A., YAMADA, M.M., CASCARDO, J.C.M. \& FURTEK, D.B. Molecular fingerprinting suggests two primary outbreaks of witches' broom disease (Crinipellis perniciosa) of Theobroma cacao in Bahia, Brazil. European Journal of Plant Pathology 105:167-175. 1999.

DHINGRA, O.D. \& SINCLAIR, J.B. Basic Plant Pathology Methods. Florida. CRC Press. 1995.

FALEIRO, F.G., BARROS, E.G., VILARINHOS, A.D., CORRÊA, R.X., PAULA JÚNIOR.,T.J. \& MOREIRA, M.A. Otimização da 
Produção de micélio de Crinipellis perniciosa em quatro meios de...

extração de DNA de esporos de Uromyces appendiculatus. Fitopatologia Brasileira 21:304- 307. 1996.

GOMES, L.M.C., MELO, G.R.P., FALEIRO, F.G., SILVA, S.D.M., ARAÚJO, I.S., BAHIA, R.C., VALLE, R.R., MORAES, M.G. \& AHNERT, D. Diversidade genética de Crinipellis perniciosa na região sul da Bahia utilizando marcadores moleculares RAPD. Proceedings, vol.1, 13th International Cocoa Research Conference, Kota Kinabalu, Sabah, Malaysia. 2000a. pp.605-612.

GOMES, L.M.C., MELO, G.R.P., FALEIRO, F.G., PIROVANI, C.P., SILVA, S.D.M., AHNERT, D. \& MORAES, M.G. Similaridade genética de isolados de Crinipellis perniciosa coletados na região cacaueira do sul da Bahia, baseada no seqüenciamento da região ITS. Genetics and Molecular Biology 23:197. 2000b. (Resumo).

SAMBROOK, J., FRITSCH, E.F. \& MANIATIS, T. Molecular Cloning: a Laboratory Manual. New York, Cold Spring Harbor Laboratory Press, Cold Spring Harbor, v.3. 1989.

THOROLD, C.A. Diseases of Cocoa. Oxford, U. K., Claredon Press. 1975.

WILLIAMS, J.G.K., KUBELIK, A.R., LIVAK, K.J., RAFALSKI, J.A. \& TINGEY, S.V. DNA polymorphisms amplified by arbitrary primers are useful as genetic markers. Nucleic Acids Research 18:7213-7218. 1990. 